\title{
Effect of Fibroblast Growth Factor 2 (FGF2) and Insulin Transferrin Selenium (ITS) on In Vitro Maturation, Fertilization and Embryo Development in Sheep
}

\author{
Sukanta Mondal", Avantika Mor, Ippala Janardana Reddy, Sumanta Nandi and PS \\ Parameswaragupta \\ National Institute of Animal Nutrition and Physiology; Adugodi, Bangalore - India
}

\begin{abstract}
The present study evaluated the effect of fibroblast growth factor 2 (FGF2) and insulin-transferrin-selenium (ITS) to the in vitro maturation and embryo culture media on ovine oocyte maturation, cleavage and embryo development. Oocytes having more than five layers of unexpanded cumulus cells and granular homogenous ooplasm were cultured into $50 \mu \mathrm{L}$ droplets of eight different culture systems: (i) TCM-199 (Tissue Culture Medium-199); (ii) TCM-199+10 ng/mL FGF2; (iii) TCM-199+20 ng/mL FGF2; (iv) TCM-199+30 ng/mL FGF2; (v) TCM-199+10 ng/mL ITS; (vi) TCM-199+20 ng/mL ITS; (vii) TCM-199+30 ng/mL ITS and (viii) TCM-199+20 ng/mL ITS+20 ng/mL FGF2 in a $\mathrm{CO}_{2}$ incubator at $38.5^{\circ} \mathrm{C}$ for $24 \mathrm{~h}$. All the oocyte culture media were supplemented with $10 \% \mathrm{FBS}, \mathrm{FSH}(10 \mu \mathrm{g} / \mathrm{mL})$ and gentamicin $(50 \mu \mathrm{g} / \mathrm{mL})$. The maturation rate was assessed based on the degree of expansion of cumulus cells and identifying first polar body extrusion into perivitelline space. The matured oocytes were inseminated with 1 to 2 million spermatozoa/mL in Brackett and Oliphant medium and the cleavage rate was checked after 42-48 $h$ post insemination and further cultured for 6-7 days. Maturation and cleavage rates were significantly higher $(P<0.05)$ in the oocytes cultured in TCM-199 +10\% FBS+FSH $(10 \mu \mathrm{g} / \mathrm{mL})$ supplemented with both $20 \mathrm{ng} / \mathrm{mL}$ ITS and $20 \mathrm{ng} / \mathrm{mL}$ FGF2 as compared to the control. It was concluded that the supplementation of ITS and FGF2 in maturation medium was beneficial for improving maturation and cleavage rates of sheep oocytes. The addition of ITS and FGF2 in embryo culture medium did not improve the development of sheep embryos.
\end{abstract}

Key words: fibroblast growth factor 2, insulin transferrin selenium, oocyte, embryo, sheep

\section{INTRODUCTION}

Oocyte maturation is the first and most critical step towards the successful in vitro embryo production. The intrinsic ability of the oocytes to resume meiosis, accept spermatozoa for fertilization, cleave after fertilization, and facilitate proper embryonic development that leads to the production of healthy offspring are dependent of various endocrine and intra-ovarian factors produced within the follicular niche (Binelli et al. 2010). Supplementing specific paracrine and endocrine components during in vitro maturation (IVM) of bovine cumulus-oocyte complexes (COCs) improved the success of in vitro embryo production and maximize embryonic competency to generate healthy offspring after embryo transfer. Various growth factors either endogenous and exogenous may be useful in oocyte maturation and growth. Previous studies have revealed that oocyte factors secreted in follicular fluid promoted the oocyte maturation (Gupta et al. 2001; 2005). The addition of ITS to in vitro maturation medium enhanced nuclear maturation $(79 \%$ vs $54 \%)$,

*Author for correspondence: sukanta781@gmail.com 
decreased polyspermy, improved embryo development and post-transfer survival $(\mathrm{Hu}$ et al. 2011). Another class of paracrine-acting factors that have received recent attention for their abilities to control follicular development and oocyte maturation are the fibroblast growth factors (FGFs). FGFs had been found to play crucial roles in folliculogenesis, including primordial follicle activation and regulation of granulosa and cumulus cell mitosis, apoptosis and glycolysis (Sugiura et al. 2007). Several other FGFs were found to be produced in oocytes and follicular somatic cells of cattle (Parrott and Skinner 1998), mice (Sugiura et al. 2007) and human (Ben-Haroush et al. 2005). In mice, FGF4 originated from inner cell mass inhibited the differentiation of trophectoderm (Feldman et al. 1995). Porcine FGF7 derived from endometrium stimulated the proliferation of trophoblast cells during the embryonic development (Ka et al. 2001). Increased bovine embryo development rates were also observed after supplementation with fibroblast growth factor 10 (FGF10), a theca derived factor (Zhang et al. 2010). A FGF of recent interest for a functional role during oocyte maturation is FGF2 (also known as basic FGF). bFGF (FGF2) acted as a mitogen, morphogen, and angiogenic factor to regulate early embryogenesis (Gospodarowicz and Bialecki 1979). The potential involvement of FGF2 in invitro maturation, fertilization and embryo development has not been examined in sheep. Hence, the present study investigated the effect of the addition of FGF2 and ITS to the maturation medium on in vitro maturation, fertilization and embryo development of sheep oocytes.

\section{MATERIALS AND METHODS}

\section{Oocyte collection and evaluation}

Ovaries were collected from non-pregnant slaughtered sheep from a local slaughterhouse and transported to the laboratory in normal saline $(0.9 \% \mathrm{NaCl})$. Ovaries having visible follicles with a diameter of 1 to $6 \mathrm{~mm}$ were aspirated using a 20$\mathrm{G}$ hypodermic needle attached to a syringe containing $0.5-1.0 \mathrm{~mL}$ of aspiration media. The aspiration medium consisted of TCM-199, Dulbecco's phosphate-buffered saline (PBS), 0.3\% bovine serum albumin, heparin $(10 \mu \mathrm{g} / \mathrm{mL})$ and gentamicin $(10 \mu \mathrm{g} / \mathrm{mL})$. Cumulus oocytes complexes were graded by the morphological appearance of the cumulus cells investments and homogeneity of ooplasm under a stereo zoom microscope (magnification 300X). Only oocytes having more than five layers of unexpanded cumulus cells and granular homogenous ooplasm were recovered and selected for in vitro maturation (IVM).

\section{Maturation of oocytes in vitro}

All the selected oocytes for IVM were washed once with aspiration medium and three times with IVM medium, then oocytes were cultured in the maturation medium, which consisted of TCM-199 (25 mM HEPES, with Earle's salt and Lglutamine, Sigma USA), supplemented with $10 \%$ FBS, FSH $(10 \mu \mathrm{g} / \mathrm{mL})$ and gentamicin $(50 \mu \mathrm{g} / \mathrm{mL})$ and finally covered with mineral oil (Sigma, USA) (oocytes cultured in groups 7-10 oocytes $/ 50 \mu \mathrm{L}$ droplet). Oocytes were cultured at $38.5^{\circ} \mathrm{C}, 5 \% \mathrm{CO}_{2}$ and $95 \%$ humidity for $24 \mathrm{~h}$. The degree of cumulus cell expansion was determined after $24 \mathrm{~h}$ of IVM and oocyte with expanded cumulus cell mass to at least two diameters away from the zona pellucida were considered as cumulus expanded. The maturation of oocytes was further evaluated by identifying the first polar body in the perivitelline space after denuding them.

\section{Experimental design}

Cumulus oocytes complexes, 7-10 in a group, were cultured into $50 \mu \mathrm{L}$ droplets of seven different culture media in 35-mm Petri dishes: (i) TCM-199; (ii) TCM-199+10 ng/mL FGF2; (iii) TCM-199+20 ng/mL FGF2; (iv) TCM-199+30 ng/mL FGF2; (v) TCM-199+10 ng/mL ITS; (vi) TCM-199+20 ng/mL ITS and (vii) TCM-199+30 $\mathrm{ng} / \mathrm{mL}$ ITS. FBS, FSH and gentamicin were added at the level of $10 \%, 10 \mu \mathrm{g} / \mathrm{mL}$ and $50 \mu \mathrm{g} / \mathrm{mL}$, respectively in all the treatment groups. The concentration of FBS added was optimal for the IVM of sheep oocytes as found in an earlier study (Mondal et al. 2013). Since both FGF2 and ITS at $20 \mathrm{ng} / \mathrm{mL}$ level were found to be optimum for in vitro maturation of sheep oocytes when used individually, the combined effect of FGF2 and ITS in maturation medium was also investigated. Maturation was assessed and determined as described above.

\section{In vitro fertilization and embryo development}

Fresh semen was collected from a ram using electronic ejaculator and spermatozoa were capacitated using Brackett and Oliphant (BO) medium, supplemented with $10 \mu \mathrm{g} / \mathrm{mL}$ heparin 
plus $2.2 \mathrm{mg} / \mathrm{mL}$ caffeine as capacitating agents. Before transfer to fertilization drops, the oocytes were washed four times in BO medium. After the matured oocytes had been denuded, they were cocultured with capacitated spermatozoa. A $5.0 \mu \mathrm{L}$ aliquot of sperm suspension, containing $1-2 \times 10^{6}$ sperm $/ \mathrm{mL}$ was added into the fertilization drop (710 oocytes per $40 \mu \mathrm{L}$ fertilization drop). Fertilization was carried out by co-incubation of sperm and oocytes at $38.5^{\circ} \mathrm{C}$ under $5 \% \mathrm{CO}_{2}$ in humidified air for 2-4 h. Thereafter, oocytes were transferred to embryo culture medium (same media as used in maturation medium except FSH) and incubated for $18-20 \mathrm{~h}$.

\section{In vitro culture (IVC)}

After $18 \mathrm{~h}$, oocytes were washed in washing media \{TCM199 with $10 \%$ FBS+gentamicin (50 $\mu \mathrm{g} / \mathrm{mL})\}$ in order to remove the attached sperms. The embryos were then cultured in the same medium as used in maturation medium, except FSH for further development in $\mathrm{CO}_{2}$ incubator at $38.5^{\circ} \mathrm{C}, 5 \% \mathrm{CO}_{2}$ and $95 \%$ humidity and the cleavage was checked after $42-48 \mathrm{~h}$ post insemination. The embryos were then further cultured for 6-7 days in order to confirm the embryonic development.

\section{Statistical analysis}

The experiment was replicated seventeen times on different days. The percentage of maturation rate, cleavage rate and embryo development rate were analyzed by one-way ANOVA, followed by Tukey's test for comparisons of more than two groups using GraphPad Prism 5 (Graph Pad Software Inc., San Diego, CA, USA). Differences between mean the values were considered significant when the probability values were < 0.05 .

\section{RESULTS}

The effect of different concentrations of FGF2 and ITS, either alone or in combination of ITS (20 $\mathrm{ng} / \mathrm{mL})$ and FGF2 (20 ng/mL) on IVM, IVF and embryo development of sheep oocytes is shown in Table 1. Supplementation of ITS at 10, 20 and 30 $\mathrm{ng} / \mathrm{mL}$ in maturation media significantly increased $(\mathrm{P}<0.05)$ the maturation rate of sheep oocytes as compared to the control. The maturation rate was significantly increased $(\mathrm{P}<0.05)$ relative to the control by supplementation of $20 \mathrm{ng} / \mathrm{mL}$ FGF2 in maturation medium. Significant increase $(\mathrm{P}<0.05)$ in cleavage rate was observed in the medium containing both $20 \mathrm{ng} / \mathrm{mL}$ ITS and $20 \mathrm{ng} / \mathrm{mL}$ FGF2 as compared to all the doses tested, except $20 \mathrm{ng} / \mathrm{mL}$ ITS. There was no significant difference in morula development rate in the media containing the different doses of ITS and FGF2 tested. Non-significant increase $(P>0.05)$ in blastocyst development was observed in the medium containing $20 \mathrm{ng} / \mathrm{mL}$ ITS relative to the control. Significant decrease $(\mathrm{P}<0.05)$ in blastocyst yield was observed in the medium containing $10 \mathrm{ng} / \mathrm{mL}$ FGF2 as compared to those observed in the media containing $20 \mathrm{ng} / \mathrm{mL}$ FGF2, $30 \mathrm{ng} / \mathrm{mL}$ FGF2 and $20 \mathrm{ng} / \mathrm{mL}$ ITS+20 ng/mL FGF2.

Table 1 - Effect of supplementation of different doses of ITS (10, 20 and $30 \mathrm{ng} / \mathrm{mL})$, FGF2 (10, $20 \mathrm{and} 30 \mathrm{ng} / \mathrm{mL})$ and combination of ITS $(20 \mathrm{ng} / \mathrm{mL})+$ FGF2 $(20 \mathrm{ng} / \mathrm{mL})$ in maturation and embryo culture medium on maturation rate, cleavage rate and embryo development of sheep oocytes.

\begin{tabular}{|c|c|c|c|c|}
\hline \multirow[t]{2}{*}{ Treatments } & \multirow{2}{*}{$\begin{array}{l}\text { Oocyte } \\
\text { cultured }\end{array}$} & \multirow{2}{*}{$\begin{array}{l}\text { Maturation rate n } \\
(\text { Mean } \pm \text { SEM })\end{array}$} & \multirow{2}{*}{$\begin{array}{l}\text { Cleavage rate } n \\
(\text { Mean } \pm \text { SEM })\end{array}$} & $\begin{array}{c}\text { Embryo development } \mathbf{n} \\
(\text { Mean } \pm \text { SEM) }\end{array}$ \\
\hline & & & & Morula - Blastocyst \\
\hline $\begin{array}{ll}\text { TCM-199+FBS } \quad(10 \%)+\end{array}$ & 158 & $101(63.83 \pm 0.51)^{\mathrm{a}}$ & $57(58.29 \pm 4.12)^{\mathrm{a}}$ & $6(18.77 \pm 4.91)^{\mathrm{a}} 3(11.50 \pm 1.51)^{\mathrm{a}}$ \\
\hline FSH $(10 \mu \mathrm{g} / \mathrm{mL})-$ Control & & & & \\
\hline Control+ITS (10 ng/mL) & 133 & $101(75.73 \pm 1.87)^{\mathrm{b}}$ & $53(53.23 \pm 4.54)^{\mathrm{a}}$ & $6(17.71 \pm 3.47)^{\mathrm{a}} \quad 2(11.11 \pm 0.0)^{\mathrm{a}}$ \\
\hline Control+ITS $(20 \mathrm{ng} / \mathrm{mL})$ & 124 & $101(81.26 \pm 1.60)^{\mathrm{b}}$ & $68(69.68 \pm 4.96)^{\mathrm{ae}}$ & $7(20.00 \pm 4.91)^{\mathrm{a}} 13(19.05 \pm 3.25)^{\mathrm{a}}$ \\
\hline Control+ITS (30 ng/mL) & 131 & $101(76.89 \pm 1.42)^{\mathrm{b}}$ & $56(57.86 \pm 4.53)^{\mathrm{a}}$ & $4(23.61 \pm 1.39)^{\mathrm{a}} 3(12.22 \pm 2.22)^{\mathrm{a}}$ \\
\hline Control+FGF2 (10 ng/mL) & 165 & $108(65.72 \pm 1.26)^{\mathrm{a}}$ & $50(46.30 \pm 2.13)^{\mathrm{acf}}$ & $9(17.85 \pm 2.00)^{\mathrm{a}} \quad 0.00^{\mathrm{abcfh}}$ \\
\hline Control+FGF2 (20 ng/mL) & 139 & $108(77.31 \pm 2.88)^{\mathrm{b}}$ & $58(53.15 \pm 2.33)^{\mathrm{a}}$ & $12(20.75 \pm 3.10)^{\mathrm{a}} 7(14.01 \pm 2.43)^{\mathrm{ad}}$ \\
\hline Control+FGF2 (30 ng/mL) & 167 & $108(64.70 \pm 1.14)^{\mathrm{a}}$ & $55(51.11 \pm 2.67)^{\mathrm{adf}}$ & $10(17.46 \pm 4.05)^{\mathrm{a}} 5(12.44 \pm 2.04)^{\mathrm{ag}}$ \\
\hline $\begin{array}{l}\text { Control + ITS }(20 \mathrm{ng} / \mathrm{mL}) \\
+ \text { FGF2 }(20 \mathrm{ng} / \mathrm{mL})\end{array}$ & 155 & $129(82.43 \pm 1.78)^{b}$ & $106(85.20 \pm 4.62)^{\text {be }}$ & $16(15.96 \pm 1.94)^{\mathrm{a}} 15(15.07 \pm 1.81)^{\mathrm{ai}}$ \\
\hline
\end{tabular}


The growth supplements, ITS and FGF2 in combination at the level of $20 \mathrm{ng} / \mathrm{mL}$ each were found to cause significant improvement $(\mathrm{P}<0.05)$ on the maturation and cleavage rates of sheep oocytes. However, the addition of ITS and FGF2, either alone or in combination in embryo culture medium did not improve the development of sheep embryos in vitro.

\section{DISCUSSION}

To the best of our knowledge, this is the first study to report the impact of FGF2 on IVM, IVF and embryo development of sheep oocytes. Here, ITS and FGF2, either alone or in combination were used as a supplement for the culture of sheep oocytes. Results suggested that the maturation and cleavage rates of sheep oocytes cultured in the presence of $20 \mathrm{ng} / \mathrm{mL}$ ITS and $20 \mathrm{ng} / \mathrm{mL}$ FGF2 combination was significantly higher in comparison to all the doses tested, except 20 $\mathrm{ng} / \mathrm{mL}$ ITS. The fertilizing ability of sheep oocytes cultured in $20 \mathrm{ng} / \mathrm{mL}$ ITS was significantly higher as compared to those observed in 10 and $20 \mathrm{ng} / \mathrm{mL}$ FGF2 alone. This suggested that ITS had more beneficial effect on sheep embryo cleavage than FGF2. The transferrin and selenium has been reported to be essential for the catalytic activity of glutathione peroxidase and could serve as the antioxidant defense system in the oocyte (Cerri et al. 2009).

The present study showed that ITS supplementation in the maturation medium resulted higher oocyte maturation as compared to the control. Increment of oocyte growth in ITS supplement group could be due to increase in glutathione (GSH) concentration in oocytes. Glutathione, a thiol tripeptide component in all cell types has an important role in the transportation of amino acid, synthesis of the protein and DNA, and reduction of disulfide bonds (Meister and Anderson 1983). Insulin promoted glucose and amino acid uptake, lipogenesis, intracellular transport, and the synthesis of proteins and nucleic acids (Spicer and Echternkamp 1995). Transferrin being an iron carrier helped to reduce the toxic levels of oxygen radicals and peroxide. Selenium, as sodium selenite, has been reported as a co-factor for glutathione peroxidase and other proteins and used as an anti-oxidant in medium (Wu et al. 1973). In cell culture system, sodium selenite protected cell from oxidative damage, free radicals and obstructed lipid perioxide products (Ebert et al. 2006). Transferrin and Selenium played a role in the antioxidant defense system in the oocyte, which was essential for the catalytic activity of glutathione peroxidase (Cerri et al. 2009).

The exposure of sheep oocytes to the medium containing FGF2 (20 ng/mL), during the maturation, increased in vitro development to the morula and blastocyst stages. The similar results were observed for early blastocyst stage development but not at earlier stages (Sugiura et al. 2009). FGF2 as an oocyte competency factor was investigated because it has been produced by theca, granulosa and cumulus cells throughout folliculogenesis (Berisha et al. 2006). The transcripts for receptors for FGF2 and many other FGFs were evident in bovine and ovine blastocysts and peri-implantation bovine and ovine conceptuses (Cooke et al. 2009). Since FGF2 is reported to be endogenously produced by cumulous cells (Berisha et al. 2006), it was hypothesized that additional supplementation of FGF2 might improve oocyte development (Gupta et al. 2002). The supplementation of FGF2 (20 $\mathrm{ng} / \mathrm{mL}$ ) promoted oocyte maturation in buffalo. Zhang and Ealy (2012) reported that FGF2 increased blastocyst formation at day 7 because early blastocyst formation in vitro was associated with increased embryo competency after embryo transfer. It was reported that FGF2 did not affect the relative abundance of transcripts encoding factors that regulate cumulus expansion (EGFR, FSHR, HAS) (Assidi et al. 2008) and other cumulus competency markers (CTSB, SPRY2) (Sugiura et al. 2009) but improved the survival rates of cumulus cells. Present results showed that the addition of ITS and FGF2 in combination in maturation medium promoted the maturation and cleavage rates of sheep oocytes. No reports were available to compare results in this aspect.

In conclusion, the results of this study showed that the supplementation of ITS and FGF2 during in vitro maturation was beneficial for enhancing the maturation and cleavage rates of sheep oocytes.

\section{ACKNOWLEDGEMENTS}

This work was supported by the National Agricultural Science Fund [formerly National Fund for Basic, Strategic and Frontier Application Research in Agriculture] (Grant number AS2002), 
Ministry of Agriculture, ICAR, New Delhi. We thank Director, NIANP for providing the necessary facilities for conducting the research work. The help rendered by A. Jagannath is duly acknowledged.

\section{REFERENCES}

Assidi M, Dufort I, Ali A, Hamel M, Algriany O, Dielemann S, et al. Identification of potential markers of oocyte competence expressed in bovine cumulus cells matured with follicle-stimulating hormone and/or phorbol myristate acetate in vitro. Biol Reprod. 2008; 79: 209-222.

Ben-Haroush A, Abir R, Ao A, Jin S, Kessler-Icekson G, Feldberg D, et al. Expression of basic fibroblast growth factor and its receptors in human ovarian follicles from adults and fetuses. Fertil Steril. 2005; 84: 1257-1268.

Berisha B, Steffl M, Amselgruber W, Schams D. Changes in fibroblast growth factor 2 and its receptors in bovine follicles before and after GnRH application and after ovulation. Reprod. 2006; 131: 319-329.

Binelli M, Murphy BD. Coordinated regulation of follicle development by germ and somatic cells. Reprod Fertil Dev. 2010; 22: 1-12.

Cerri RL, Rutigliano HM, Lima FS, Araujo DB, Santos JE. Effect of source of supplemental selenium on uterine health and embryo quality in high producing dairy cows. Theriogenol. 2009; 71: 1127-1137.

Cooke FN, Pennington KA, Yang Q, Ealy AD. Several fibroblast growth factors are expressed during preattachment bovine conceptus development and regulate interferon-tau expression from trophectoderm. Reprod. 2009; 137: 259-269.

Ebert R, Ulmer M, Zeck S, Meissner Weigl J, Schneider D, Stopper H, et al. Selenium supplementation restores the antioxidative capacity and prevents cell damage in bone marrow stromal cells in vitro. Stem Cells. 2006; 24: 1226-1235.

Feldman W, Poueymirou VE, Papaioannou TM, Dechiara M. Goldfarb Requirement of FGF-4 for postimplantation mouse development. Science. 1995; 267: 246-249.

Gospodarowicz D, Bialecki H. Fibroblast and epidermal growth factors are mitogenic agents for cultured granulosa cells of rodent, porcine, and human origin. Endocrinol. 1979; 104: 757-764.

Gupta PSP, Manjunatha BM, Nandi S, Sarma PV. In vitro maturation of buffalo oocytes with epidermal growth factor and fibroblast growth factor. Ind $J$ Anim Sci. 2002; 72(1): 23-26.
Gupta PSP, Ravindra JP, Nandi S, Raghu HM, Ramesha KP. Isolation of an oocyte stimulatory peptide from the ovarian follicular fluid of water Buffalo (Bubalus bubalis). Asian Aust J Anim Sci. 2005; 18(11): 1557-1563.

Gupta PSP, Nandi S, Ravindranatha BM, Sarma PV. Effect of buffalo follicular fluid alone and in combination with PMSG and M199 on in vitro buffalo oocyte maturation. Asian Aust J Anim Sci. 2001; 14(5): 693-696.

$\mathrm{Hu}$ J, Ma X Bao, J, Li W, Cheng D. Insulin-transferrinselenium (ITS) improves maturation of porcine oocytes in vitro. Zygote. 2011; 19: 191-197.

Ka H, Jaeger LA, Johnson GA, Spencer TE, Bazer FW. Keratinocyte growth factor is up-regulated by estrogen in the porcine uterine endometrium and functions in trophectoderm cell proliferation and differentiation. Endocrinol. 2001; 142: 2303-2310.

Meister A, Anderson ME. Glutathione. Annu Rev Biochem. 1983; 52: 711-760.

Mondal S, Mor A, Nandi S, Reddy IJ. Maturation of sheep oocytes in vitro. In: Proceedings of 13th Indian Veterinary Congress, IAHVB and Veterinary College: Bangalore; 16-17 April, 2013, pp 132.

Parrott JA, Skinner MK. Developmental and hormonal regulation of keratinocyte growth factor expression and action in the ovarian follicle. Endocrinol. 1998; 139: 228-235.

Spicer LJ, Echternkamp SE. The ovarian insulin and insulin-like growth factor system with an emphasis on domestic animals. Domest Anim Endocrinol. 1995; 12: 223-245.

Sugiura K, Su YQ, Diaz FJ, Pangas SA, Sharma S, Wigglesworth K, et al. Oocyte-derived BMP15 and FGFs cooperate to promote glycolysis in cumulus cells. Dev. 2007; 134: 2593-2603.

Sugiura K, Su YQ, Li Q, Wigglesworth K, Matzuk MM, Eppig JJ. Fibroblast growth factors and epidermal growth factor cooperate with oocytederived members of the TGFbeta superfamily to regulate Spry 2 mRNA levels in mouse cumulus cells. Biol Reprod. 2009; 81: 833-841.

Wu D, Cheung QCK, Wen L, Li J. Effect of selenium, vitamin $\mathrm{E}$ and antioxidants on testicular function in rats. Biol Reprod. 1973; 8: 625-629.

Zhang K, Hansen PJ, Ealy AD. Fibroblast growth factor 10 enhances bovine oocyte maturation and developmental competence in vitro. Reprod. 2010; 140: 815-826.

Zhang K, Ealy AD. Supplementing fibroblast growth factor 2 during bovine oocyte in vitro maturation promotes subsequent embryonic development. Open J Anim Sci. 2012; 2(2):119-126. 